\title{
The bloodsucking biting midges of Argentina (Diptera: Ceratopogonidae)
}

\section{Gustavo R Spinelli+ , María M Ronderos, Florentina Díaz, Pablo I Marino}

\author{
División Entomología, Museo de La Plata, Paseo del Bosque s/n, 1900 La Plata, Argentina
}

\begin{abstract}
A key is presented for the identification of the adults of 54 species of bloodsucking ceratopogonids, 51 of which are known inhabitants of Argentina, and Culicoides uruguayensis Ronderos, C. pifanoi Ortiz, and C. trilineatus Fox, which are known to occur in bordering Uruguay and Paraguay. Wing photographs are provided of females of the 45 species of Culicoides. Three new species of Culicoides Latreille from Northeastern Argentina are described and illustrated: C. austroparaensis Spinelli, C. bachmanni Spinelli, and C. williamsi Spinelli. The following six species are recorded for the first time from Argentina and/or bordering localities in Paraguay: Leptoconops brasiliensis (Lutz), C. gabaldoni Ortiz, C. ginesi Ortiz, C. pifanoi Ortiz, C. pseudocrescentis Tavares and Luna Dias, and C. trilineatus; and C. estevezae Ronderos and Spinelli is newly recorded from Misiones province of Argentina. C. lopesi Barretto is excluded from the Argentinean ceratopogonid fauna.
\end{abstract}

Key words: Diptera - Ceratopogonidae - biting midges - hematophagous - key - new species - Argentina

Of the 102 living genera of Ceratopogonidae listed in the recent world catalog by Borkent and Wirth (1997), females of only the following four suck blood from vertebrates: Austroconops Wirth and Lee, endemic to Australia, and the cosmopolitan Leptoconops Skuse, Forcipomyia Meigen (only species included in the subgenus Lasiohelea Kieffer) and Culicoides Latreille.

The medical and veterinary importance of these species in Argentina was recently reviewed by Ronderos et al. (2003), and the taxonomic status of the bloodsucking species in the country was treated by Ronderos and Spinelli (1992) for Leptoconops, Ronderos and Spinelli (1999), Marino and Spinelli (2005) for Forcipomyia (Lasiohelea) and Ronderos and Spinelli (2002) for Culicoides.

As a result of several collecting trips to northern sites in Argentina and Paraguay, material containing three undescribed species of Culicoides and several hitherto previously unrecorded species of Leptoconops and Culicoides for Argentina were processed and accessioned into the entomological collection of the Museo de La Plata. This paper deals with the description and illustration of three previously undescribed species, as well to provide a key for the identification of 54 species of bloodsucking ceratopogonids, 51 of which are known inhabitants of Argentina, and C. uruguayensis Ronderos, C. pifanoi Ortiz, and $C$.trilineatus Fox, which are known to occur in bordering Uruguay and Paraguay.

Forattini (1957) recorded C. lopesi Barretto from Argentina, based on two females from Misiones province. During the present study these two females were re-examined and we determined that they actually belong to two different species. These specimens are mounted in Canada balsam, are very damaged and unidentifiable, but

${ }^{+}$Corresponding author.

E-mail:spinelli@museo.fcnym.unlp.edu.ar

Received 14 September 2004

Accepted 12 January 2005 it could be verified that the antenna of both species differ from the one described by Forattini (1957) as the antenna of $C$. lopesi. Therefore, we conclude that $C$. lopesi is not present in Argentina.

\section{MATERIALSAND METHODS}

Specimens were slide mounted in Canada balsam and examined, measured, and drawn using a binocular compound microscope with attached camera lucida. Types of the new species, as well as the remaining specimens examined are deposited in the collection of the División Entomología, Museo de la Plata, Argentina (MLPA). Illustrations are based on types. All specimens were collected biting or with different types of light traps.

Terms for structures follow those used in the Manual of Nearctic Diptera (McAlpine et al. 1981). Terms for wing veins follow the system in the Manual of Nearctic Diptera, with modifications proposed by Szadziewski (1996). Names of veins are in upper case and those cells in lower case. Pale areas in cell $r_{3}$ posterior to or immediately distal to second radial cell are called poststigmatic pale spots. Four abbreviated terms are used in the text: antennal ratio (AR) is the combined length of the five distal flagellomeres divided by the combined length of the eight proximal ones; palpal ratio (PR) is the length of the third palpal segment divided by its greatest width; proboscis/head ratio $(\mathrm{P} / \mathrm{H}$ ratio) is the length of the proboscis measured from the distal end of the labrum-epipharynx to the anterior margin of the tormae, divided by the distance measured from the anterior margin of the tormae to the median hair socket between the eyes; costal ratio (CR) is obtained by dividing the length of the costa by wing length, measuring both from the level of the basal arculus of the wing.

\section{RESULTS}

Key to species

1. Eyes widely separated dorsally, lacking frontal suture; female antenna with 12 flagellomeres; palpus with four segments (only one beyond elongate and/or swollen third) and with membranous gap between segment 3 
and 4+5; wing whitish hyaline without macrotrichia, crossvein $\mathrm{r}-\mathrm{m}$ absent, female with radial cells fused into swollen stigma; female cerci very elongate (except subgenus Brachyconops Wirth and Atchley); male gonostylus with an apical, socketed peg (Leptoconops Skuse)

- Eyes narrowly separated dorsally, with frontal suture; female antenna with 13 flagellomeres; palpus with five segments but with a membranous gap between the last two segments; wing with numerous or scattered macrotrichia, crossvein r-m present, female with radial cells not fused; female cerci short; male gonostylus without apical, socketed peg although apex may be pointed....

2. Female cerci short; tarsomeres 1-2 of foreleg with strong spines, other tarsomeres with slender, sharp, or inconspicuous spines only; tarsal claws of female each with basal, bifid tooth (subgenus Brachyconops) L. (B.) patagoniensis Ronderos

- Female cerci very elongate; female tarsi without strong ventral spines, or with spines only at apices of tarsomere 1 of foreleg, or with a few moderately strong ventral spines on tarsomere 1 of foreleg and at apices of distal tarsomeres (subgenus Leptoconops Skuse)

3. CR 0.20 ..... L. (L.) petrocchiae Shannon and Del Ponte

- $\quad$ CR 0.40-0.50 4

4. Apical flagellomere 2.0-2.6 times longer than broad

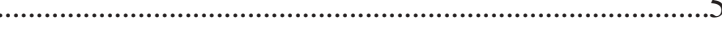

Apical flagellomere 4-5 times longer than broad

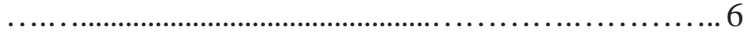

5. Apical flagellomere twice as long as broad; third palpal segment slender, with small, rounded sensory pit; hind tibial comb with four spines, second from spur longest; three spermathecae .......... L. (L.) chilensis Forattini

- Apical flagellomere 2.6 times longer than broad; third palpal segment broad, with large sensory pit; hind tibial comb with four spines, second and third from spur longest; two spermathecae

$$
\text { L. (L.) ricardoi Ronderos and Spinelli }
$$

6. Apical flagellomere with conical apex; third palpal segment pale brown, subequal to fourth, which bears a pale basal ring; longitudinal veins abutting wing margin .... L. (L.) brasiliensis (Lutz)

- Apical flagellomere with blunt apex; third palpal segment 1.5 times longer than fourth, both entirely dark brown; longitudinal veins not abutting wing margin L. (L.) casali Cavalieri and Chiossone

7. Wing with numerous macrotrichia, without distal pattern of dark and/or light pigmentation; apical flagellomere with terminal nipple which is constricted basally; claws strongly curved; empodia well developed (Forcipomyia Meigen, subgenus Lasiohelea Kieffer).
- Wing with scattered macrotrichia on apical half of the wing (a few species have some macrotrichia more basally on the wing but these are scattered), with or without distinct pattern of dark and/or light pigmentation; apical flagellomere without terminal nipple; claws only slightly curved; empodia poorly developed ( $\mathrm{Culi}$ coides Latreille)

8. CR 0.50 F. (L.) saltensis (Cavalieri)

- CR0.60 9

9. Third palpal segment fusiform, palpal ratio 1.90-2.10; cibarial armature with 9-10 spines in one row; sclerites of aedeagus contacting at $2 / 3$ of total length, distal portion elongate, directed lateroposteriorly

F. (L.) stylifer (Lutz)

- $\quad$ Third palpal segment greatly swollen, PR 1.27-1.55; cibarial armature with 12-15 spines in one row; sclerites of aedeagus in contact their entire length, distal portion very short, divergent, forming right angles F. (L.) anitae Huerta and Ibañez-Bernal

10.Wing without pattern of pale and dark spots .......... 11

- Wing with pattern of pale and dark spots ............13

11.Large species, wing length $1.30 \mathrm{~mm}$; sensilla coeloconica on flagellomeres 3-10

C. irwini Spinelli and Wirth (Fig. 1)

- Smaller species, wing length less than 1.10 mm; sensilla coeloconica on different flagellomeres ............12

12. Sensilla coeloconica on flagellomeres 1, (5), 6-8, (9-10), 11-12, (13); halter dark brown; eyes bare; aedagus with bifid apex; parameres without distal fringe ..... C. caridei (Brèthes) (Fig. 2)

Sensilla coeloconica on flagellomeres 1, 6, (7-8), (11), 12, (13); halter pale brown; eyes pubescent between lower ommatidia; apex of aedeagus concave; parameres with distal fringe

....... C. patagoniensis Ronderos and Spinelli (Fig. 3)

13.Pale spots at periphery of wing very faint .... 14

Pale spots at periphery of wing well defined .... 16

14.Small species, wing length $0.64 \mathrm{~mm}$; eyes contiguous, pubescent; wing nearly bare of macrotrichia; poststigmatic pale spots abutting vein $\mathrm{M}_{1}$; legs yellow except for dark knees ..... C. pusillus Lutz (Fig. 4)

- $\quad$ Larger species, wing length $1.00 \mathrm{~mm}$ or greater; eyes separated, bare; wing with abundant macrotrichia; poststigmatic pale spot not abutting vein $\mathrm{M}_{1}$; legs brown, femora with or without pale rings ................ 15

15. Third palpal segment with deep pit; femora without pale rings; sensilla coeloconica on flagellomeres 1, 58; CR 0.62 . C. bambusicola Lutz (Fig. 5)

- Third palpal segment with broad, shallow pit; fore and midfemora with subapical pale rings; sensilla coeloconica on flagellomeres 1, 6-8; CR 0.53 C. pampaensis Spinelli and Wirth (Fig. 6) 
16. Second radial cell wholly or mainly included in a light spot . 17

- Second radial wholly included in a dark spot 28

17. Wing dark, with well separated pale spots, veins $\mathrm{CuA}_{1}$ and $\mathrm{CuA}_{2}$ pale bordered in cell cua1; sensilla coeloconica on flagellomeres 1, 9-13 or 1, (2), 3, (4), 5, (6), 7, (8), 9-13; legs dark brown, femora and tibiae with pale rings . .18

- Wing with large, interconnected pale spots; sensilla coeloconica on flagellomeres 1-13; legs yellowish except for dark knee spots C. nigrigenus Wirth and Blanton (Fig. 7)

18. Cell $\mathrm{m} 1$ with one pale spot distal to the double spot straddling vein $\mathrm{M}_{2}$. 19

- Cell m1 with two pale spots distal to the double spot straddling vein $\mathrm{M}_{2}$. 23

19. Crossvein $r-m$ dark on anterior half; vein $R_{3}$ blackened into adjacent distal pale area up to a point where vein turns abruptly forward to meet the costa; sensilla coeloconica on flagellomeres $1,(2), 3,(4), 5,(6), 7,(8)$, 9-13; mandible with 21-23 teeth; third palpal segment with definite, irregular pit

C. insignis Lutz (Fig. 8)

- Crossvein r-m pale or dark on anterior half; vein $\mathrm{R}_{3}$ pale or if slightly infuscated, sensilla coeloconica on flagellomeres 1, 9-13 (variable on flagellomeres 5 and 7 in C.fernandoi); mandible with 13-18 teeth; pit of third palpal segment various 20

20. Crossvein r-m dark 21

- Crossvein r-m pale 22

21. Eyes V-shaped where they contact; PR 1.90; vein $\mathrm{R}_{3}$ with a small blackish spot just beyond apex; vein $\mathrm{CuA}_{2}$ with apical pale spot; mandible with 18 teeth C. charruus Spinelli and Martínez (Fig. 9)

- Eyes contiguous by distance equal to diameter of 1.5 ommatidia; $P R$ 4.00; vein $\mathrm{R}_{3}$ pale, without blackish spot just beyond apex; apex of vein $\mathrm{CuA}_{2}$ dark; mandible with 13 teeth.

C. biestroi Spinelli and Ronderos (Fig. 10)

22. Yellowish brown species; third palpal segment with subdivided pit; palpal ratio 3.30; mandible with 12-14 teeth; halter knob dark

..C. ferreyrai Ronderos and Spinelli (Fig. 11)

- Brown species; third palpal segment stout, with irregular pit; palpal ratio 2.40; mandible with 17-19 teeth; halter knob pale

C. lutzi Costa Lima (Fig. 12)

23. Crossvein $r-m$ pale; wing pattern with extensive pale areas predominant ...C. brasilianum Forattini (Fig. 13)

- Crossvein r-m dark, or at least faintly infuscated; wing with pale areas smaller, contrasting ................ 24

24. Vein $\mathrm{R}_{3}$ with a small black spot just beyond apex ...... 25
- Vein $\mathrm{R}_{3}$ pale, without black spot just beyond apex ... 26

25. Sensilla coeloconica on flagellomeres 1, 9-13; third palpal segment very elongated, with shallow, rounded pit, PR 4.20; $\mathrm{P} / \mathrm{H}$ ratio 1.22; tergite 9 of male with widely spaced apicolateral processes; apex of aedeagus truncated

C. foxi Ortiz (Fig. 14)

- Sensilla coeloconica on flagellomeres 1, (5), (7), 9-13; third palpal segment swollen at midportion, with irregular pit, PR 3.50; $\mathrm{P} / \mathrm{H}$ ratio 1.00; tergite 9 of male with closer apicolateral processes; apex of aedeagus with terminal papilla

C. fernandoi Tavares and Souza (Fig. 15)

26. Large, blackish species; mandible with 20 -23 very small teeth; scutum with prominent pattern .

C. ignacioi Forattini (Fig. 16)

- Medium-sized, brown species; mandible with 13-18 stouter teeth; scutum without prominent pattern

27. Crossvein r-m very dark on anterior half; third palpal segment with irregular pit, PR 3.00-3.35 ........

C. plaumanni Spinelli (Fig. 17)

- Crossvein r-m only faintly darkened on anterior half; third palpal segment elongate, with capitate sensilla in a shallow pit (with 2-3 other shallow depressions in a few specimens), PR 3.60-5.35.

C. guttatus (Coquillett) (Fig. 18)

28. Wing with pale spot straddling middle of vein $\mathrm{M}_{2}$, or veins $M_{1}$ and $M_{2}$ entirely pale-margined, including this area ....

- Wing with no pale spot straddling vein $\mathrm{M}_{2}$, this vein usually dark to apex 36

29.Wing with extensive, interconnected pale markings (cell $\mathrm{m}_{1}$ with distal pale spot shorter than dark area between it and wing margin; cell $r_{3}$ with poststigmatic pale spot not enclosing a dark spot behind second radial cell; scutum yellowish with dark brown sublateral bands) .............. C. pifanoi Ortiz (Fig. 19)

- Wing dark with well separated pale spots............. 30

30.Vein $M_{1}$ with pale spot present straddling basal portion; sensilla coeloconica on flagellomeres 1, 9-13

.31

- Vein $M_{1}$ without pale spot straddling basal portion; distribution of sensilla coeloconica different from above .................................................... 33

31. One spermatheca without sclerotized neck; two separate, small, distal pale spots in cell cell $r_{3}$; fore, mid femora with subapical pale rings ....

C. uruguayensis Ronderos (Fig. 20)

- Two spermathecae; distal pale spots in cell cell $r_{3}$ fused

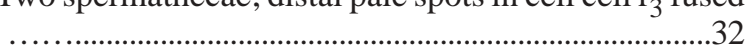

32.Small species, wing length $1.10 \mathrm{~mm}$; spermathecae ovoid, length $0.044,0.035 \mathrm{~mm}$, respectively ........ 
C. chacoensis Spinelli and Wirth (Fig. 21)

- Larger species, wing length $1.25 \mathrm{~mm}$; spermathecae subspherical, length $0.035,0.028 \mathrm{~mm}$, respectively ............... C. saltaensis Spinelli and Wirth (Fig. 22)

33. Cell $\mathrm{m}_{1}$ with two pale spots past the pale spots straddling vein $\mathrm{M}_{2}$; cell $\mathrm{r}_{3}$ with six small round pale spots

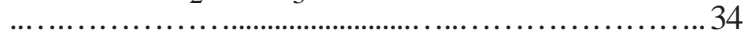

- Cell $\mathrm{m}_{1}$ with one distal pale spot past the pale spots straddling vein $\mathrm{M}_{2}$; pale spot in cell $\mathrm{r} 3$ not as above, distal one crescent-shaped 35

34.Sternite 9 of male with broad, shallow posteromedial excavation; third palpal segment with shallow pit; hind tibial comb with five spines

$$
\text { C. venezuelensis Ortiz and Mirsa (Fig. 23) }
$$

- Sternite 9 of male with deep, inverted V-shaped posteromedial excavation; third palpal segment with broad, deep pit; hind tibial comb with six spines ......... C. lacustris Ronderos (Fig. 24)

35. Cell $r_{3}$ with pale spot lying in front of vein $M_{1}$ located between poststigmatic and the crescent-shaped, distal pale spot

C. crescentis Wirth and Blanton (Fig. 25)

- Cell $r_{3}$ without pale spot lying in front of vein $\mathrm{M}_{1} \ldots \ldots$. ..C. pseudocrescentis Tavares and Luna Dias (Fig. 26)

36.Cell $\mathrm{m}_{2}$ with two (or one with at least part of a second) pale spot lying distal to level of cubital fork ............ 37

- Cell $\mathrm{m}_{2}$ with one pale spot lying distal to level of cubital fork, not including any spot lying immediately anterior to base of fork .. 42

37. Distal pale spot in cell $\mathrm{m}_{1}$ broadly abutting wing margin .

- Distal pale spot in cell $\mathrm{m}_{1}$ not abutting wing margin

8. Apices of veins $\mathrm{M}_{1}, \mathrm{M}_{2}$ dark; hind femur with subapical pale ring C. limai Barretto (Fig. 27)

- Apices of veins $\mathrm{M}_{1}, \mathrm{M}_{2}$ pale; hind femur dark to apex......

C. boliviensis Spinelli and Wirth (Fig. 28)

39. Second radial cell long, CR 0.75; scutum dark brown, without prominent pattern

C. cuiabai Wirth (Fig. 29)

- Second radial cell shorter, CR less than 0.65; scutum with prominent pattern of punctiform dots

40.Anal cell with one distal pale spot; distal pale spot in cell $r_{3}$ not abutting wing margin; legs largely pale C. aureus Ortiz (Fig. 30)

- Anal cell with two distal pale spots; distal pale spot in cell $r_{3}$ abutting wing margin; legs dark brown, with pale rings

41.One spermatheca; pale spot on crossvein r-m extensive; pale spot present behind second radial cell, proxi- mal to the poststigmatic pale spots; poststigamtic pale spots longitudinally aligned, posterior one smaller; distal pale spot in cell $r_{3}$ large, with narrow proximal extension

C. leopoldoi Ortiz (Fig. 31)

- Two spermathecae; pale spot on crossvein r-m narrow; with separate pale spot distal to crossvein r-m; without pale spot behind second radial cell; poststigmatic pale spots subequal, posterior one located proximal to the other; distal pale spot in cell $r_{3}$ divided in two small pale spots, without proximal extension C. williamsi Spinelli n. sp. (Fig. 32)

42. Sensilla coeloconica on flagellomeres 1,9-12 C. guarani Ronderos and Spinelli (Fig. 33)

Sensilla coeloconica absent on flagellomeres 9-12

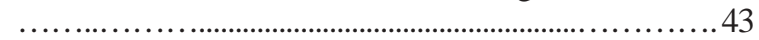

43.One spermatheca ..C. estevezae Ronderos and Spinelli (Fig. 34)

- Two spermathecae 44

44.Cell $r_{3}$ with three pale spots (two poststigmatic, and one located between the poststigmatic pale spots and wing margin); cell $\mathrm{m}_{1}$ with two pale spots (additional, faint third pale spot may be present in $C$. dureti and $C$. trilineatus)

Cell $r_{3}$ with fourth, apical pale spot; cell $\mathrm{m}_{1}$ with three pale spots .... 45

45.Distal portion of parameres with well developed ventral lobe, tapered to fine point with lateral fringe of fine spines.

C.paraensis (Goeldi) (Fig. 35)

- Distal portion of parameres sinuate, without ventral lobe, tapered to simple tip without lateral fringe of spines .........C. austroparaensis Spinelli n.sp. (Fig. 36)

46.Sensilla coeloconica on flagellomeres $1,4-8$.......... ..C. trilineatus Fox (Fig. 37)

- Sensilla coeloconica on flagellomeres $1,5-8$ or 1, 6-8 .. 47

47.Poststigmatic pale spot fused, longitudinally aligned; third palpal segment moderatelly swollen, with deep pit ... 48

- Poststigmatic pale spot oblique, posterior one located proximal to the other; third palpal segment slender, with shallow pit ...................................... 50

48.Palpus pale yellowish C. gabaldoni Ortiz (Fig. 38)

- Palpus dark brown .49

49. Flagellomeres 9-10 subequal to preceding and following ones C. horticola Lutz (Fig. 39)

- Flagellomeres 9-10 clearly shorter than preceding and following ones

..C. bachmanni Spinelli n. sp. (Fig. 40)

50.Scutum with prominent pattern of punctiform brown 
dots; pale spot present anterior to cubital fork; distal pale spots in cells $\mathrm{m}_{2}$ and cua 1 not abutting wing margin ............................ ginesi Ortiz (Fig. 41)

- Scutum without prominent pattern; no pale spot anterior to cubital fork; distal pale spots in cells $\mathrm{m}_{2}$ and cua $_{1}$ abutting wing margin .................................51

51. Sensilla coeloconica on flagellomeres $1,5-8 \ldots \ldots \ldots . .52$

- Sensilla coeloconica on flagellomeres 1, 6-8 ........ 53

52. Flagellomeres 8, 9 subequal, AR 0.82; additional, faint third pale spot in cell $\mathrm{m}_{1}$ abbuting wing margin; small dark spot just behind second radial cell; spermathecae with short necks

.C. dureti Ronderos and Spinelli (Fig. 42)

- Flagellomere 8 clearly shorter than 9,AR 1.19; without additional third pale spot in cell $\mathrm{m}_{1}$; without dark spot behind second radial cell; spermathecae with long necks ........................... .flinti Wirth (Fig. 43)

53. Third palpal segment stout, PR 2.00-2.60; flagellomere 8 longer than 9; distal pale spot in cell $\mathrm{m}_{1}$ separated from wing margin by a distance aproximate to its length; macrotrichia distributed on distal 2/3 of wing, extending in at least two rows to base of cell $\mathrm{m}_{2}$; halter brown C. debilipalpis Lutz (Fig. 44)

- $\quad$ Third palpal segment long, slender, PR 3.70-4.00; flagellomere 8 slightly shorter than 9; distal pale spot in cell $\mathrm{m}_{1}$ separated from wing margin by a distance equal to twice its length; macrotrichia distributed on distal half of wing, not reaching base of cell $\mathrm{m}_{2}$; halter pale ............................... . lahillei (Iches) (Fig. 45)

\section{DESCRIPTION OF NEW SPECIES}

Culicoides austroparaensis Spinelli, n. sp. (Figs 36, 46-52)

Diagnosis - Male: only species of the paraensis species group in which the distal portion of the parameres lack a ventral lobe and tapers to simple tip, without lateral fringe of spicules, and tergite 9 with very short, slender apicolateral processes. Female: indistinguishable from $C$. paraensis.

Male. Similar to female with usual sexual differences. Flagellum as in Fig. 46. Wing length $0.82 \mathrm{~mm}$; width $0.36 \mathrm{~mm}$; CR 0.52. Genitalia (Fig. 47): tergite 9 long, with very short, slender apicolateral processes, small posteromedial notch; sternite 9 short, with narrow, moderately deep posteromedial excavation. Gonocoxite stout, $1.35 \mathrm{X}$ as long as broad, ventral root large, foot-shaped, posterior heel blunt, dorsal root slender; gonostylus as long as gonocoxite, broad basally, apex curved. Parameres (Fig. 48) separate, each with large, basal knob; basal portion slender, abruptly bent near base, distal portion sinuate, without ventral lobe, tapering to simple tip without lateral fringe of spicules. Aedeagus V-shaped, lateral arms slender, strongly sclerotized; basal arch pointed; posteromedial projection with simple, narrowly rounded tip.

Female. Head brown. Eyes with dense pubescence, separated by distance equal to diameter of one ommatidium (Fig. 49). Flagellum (Fig. 50) pale brown, flagellomere 8 subequal to 9; AR $0.75(0.68-0.80, \mathrm{n}=3)$; sensilla coeloconica on flagellomeres 1, 6-8. Palpus (Fig. 51) pale brown; third segment moderately slender with small, deep pit; PR 2.85 (2.20-3.20, $\mathrm{n}=3)$; $\mathrm{P} / \mathrm{H}$ ratio $0.86(\mathrm{n}=3)$. Mandible with $12-16(n=3)$ teeth.

Thorax: scutum dark brown, without pattern. Legs dark brown; fore, mid femora with subapical, tibiae with subbasal pale rings, hind tibia pale distally; hind tibial comb with four spines, second from spur longest. Wing (Fig. $36)$, length $0.85(0.82-0.87, \mathrm{n}=3) \mathrm{mm}$; width $0.41(0.40-0,42$, $\mathrm{n}=3) \mathrm{mm}$; CR $0.57(\mathrm{n}=3)$; with second radial cell in dark spot; pale spot on crossvein r-m small, rounded, barely abutting costal wing margin; poststigmatic pale spots in cell $r_{3}$ small, rounded, posterior one located distinctly proximal to anterior one; two additional pale spots in cell $r_{3}$, anterior one small, located in center of cell, distal one near apex of cell; cell $\mathrm{m}_{1}$ with three pale spots; cell $\mathrm{m}_{2}$ with one distal pale spot, another lying anterior to cubital fork, another behind crossvein $\mathrm{r}-\mathrm{m}$; cell cua ${ }_{1}$ with small pale spot not abutting wing margin nor veins $\mathrm{CuA}_{1}, \mathrm{CuA}_{2}$; anal cell with one distal pale spot well separated from wing margin; apices of veins $\mathrm{M}_{1}, \mathrm{M}_{2}, \mathrm{CuA}_{1}, \mathrm{CuA}_{2}$ dark. Macrotrichia very sparse on distal half of wing, a few on base of anal cell and on distal portion of cell $\mathrm{m}_{2}$. Halter pale.

Abdomen: brown. Two ovoid spermathecae with sclerotized necks (Fig. 52), larger measuring $0.048(n=3)$ by $0.040(\mathrm{n}=3) \mathrm{mm}$, neck length $0.008 \mathrm{~mm}$, width $0.005 \mathrm{~mm}(\mathrm{n}$ $=3)$, smaller measuring $0.040(\mathrm{n}=3)$ by $0.032(\mathrm{n}=3) \mathrm{mm}$, neck length $0.008 \mathrm{~mm}$, width $0.003 \mathrm{~mm}(\mathrm{n}=3)$; rudimentary third, ring present.

Distribution - Known only from its type-locality in northern Corrientes province of Argentina.

Taxonomic discussion - This new species is a typical member of the $C$. paraensis group in the subgenus Haematomyidium Goeldi. Wirth and Felippe-Bauer (1989) reviewed the group, treating the hitherto known four species, C. paraensis, C. quasiparaensis Clastrier, C. neoparaensis Tavares and Souza, and C. filiductus Wirth. Two more species belonging to this group, $C$. diversus Felippe-Bauer, and C. peruvianus Felippe-Bauer, were recently described from the Peruvian Amazonia (FelippeBauer et al. 2003).

The male of this new species is very distinctive, unique within the paraensis group due to the absence of a lateral fringe of spicules on the distal portion of parameres. The parameres lacking a ventral lobe is a character only shared by C. quasiparensis, but females of this species differ from C. austroparensis by the stouter third palpal segment and by the very narrowly separated eyes. The females of C. austroparaensis are indistinguishables from those of $C$. paraensis.

There is one male specimen from the type-locality which also lacks the lateral fringe of spicules on the distal portion of parameres. However, this specimen has a tergite 9 with stout, triangular apicolateral processes. It may be a variant of $C$. austroparaensis but due to this difference, we do not designate it as a paratype.

The male and female of this species were associated by their shared pigmentation patterns and were collected together at the type locality.

Types - Holotype male, allotype female, Argentina, 

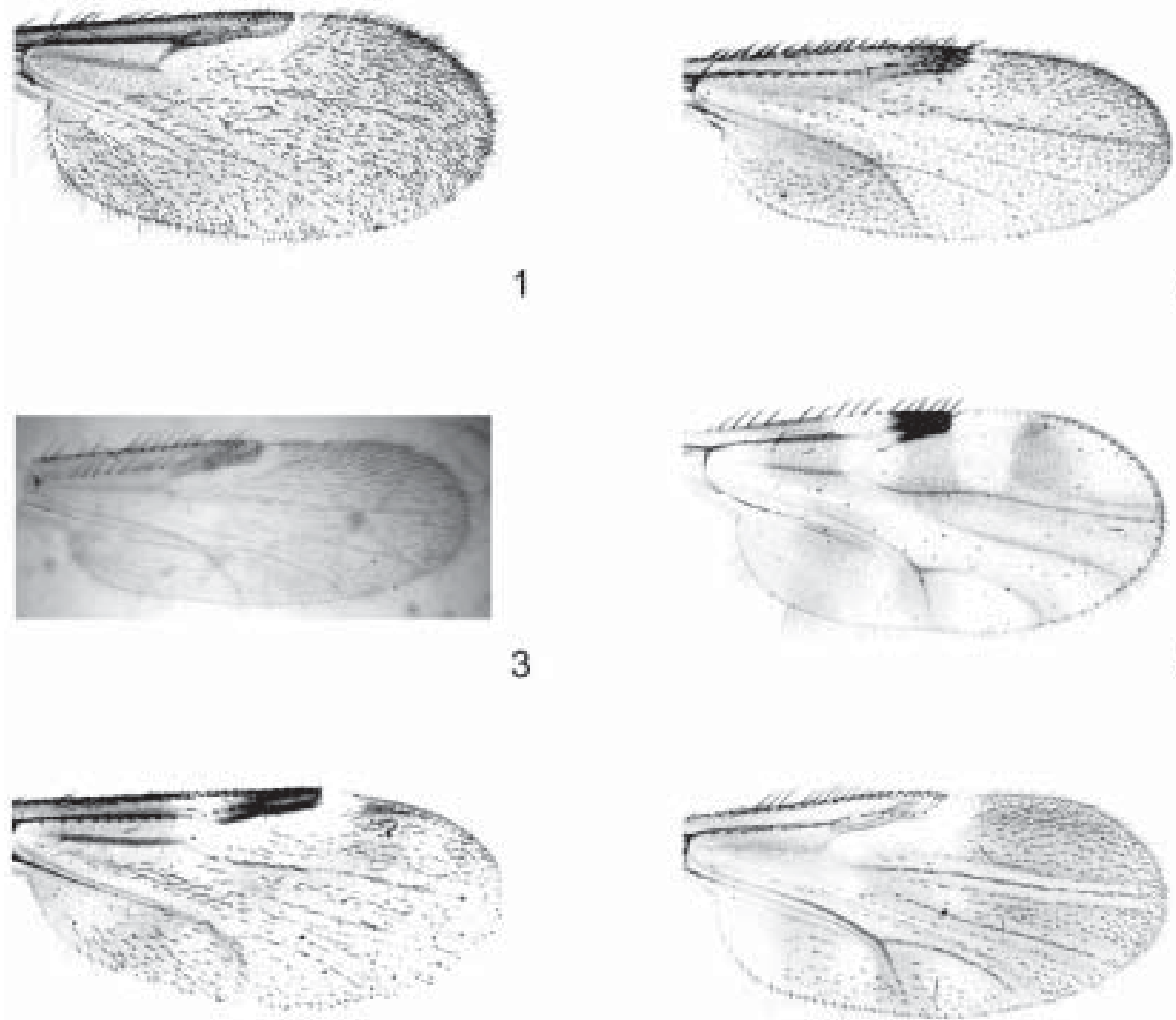

5
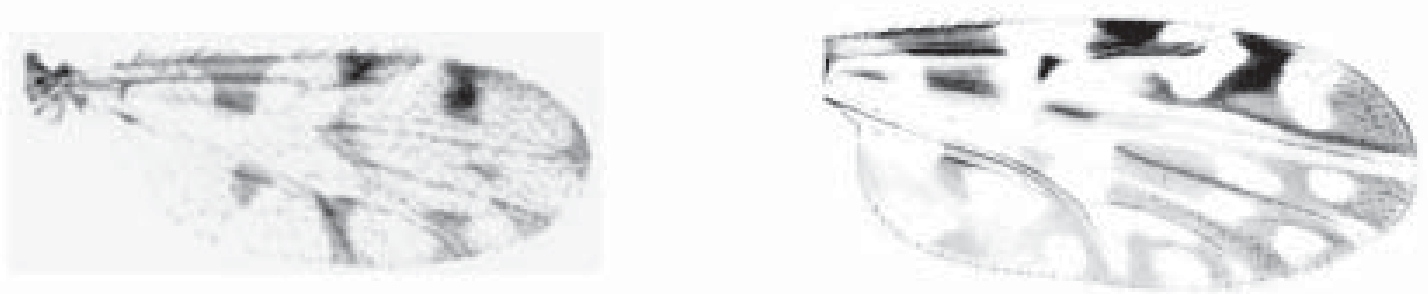

7
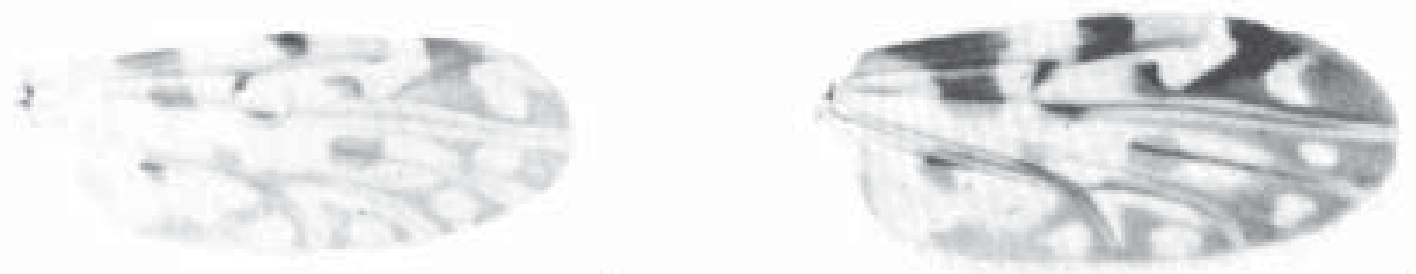

Figs 1-10: photographs of female wings of Culicoides from Argentina. 1: C. irwini; 2: C. caridei; 3: C. patagoniensis; 4: C. pusillus; 5: C. bambusicola; 6: C. pampaensis; 7: C. nigrigenus; 8: C. insignis; 9: C. charruus; 10: C. biestroi. 

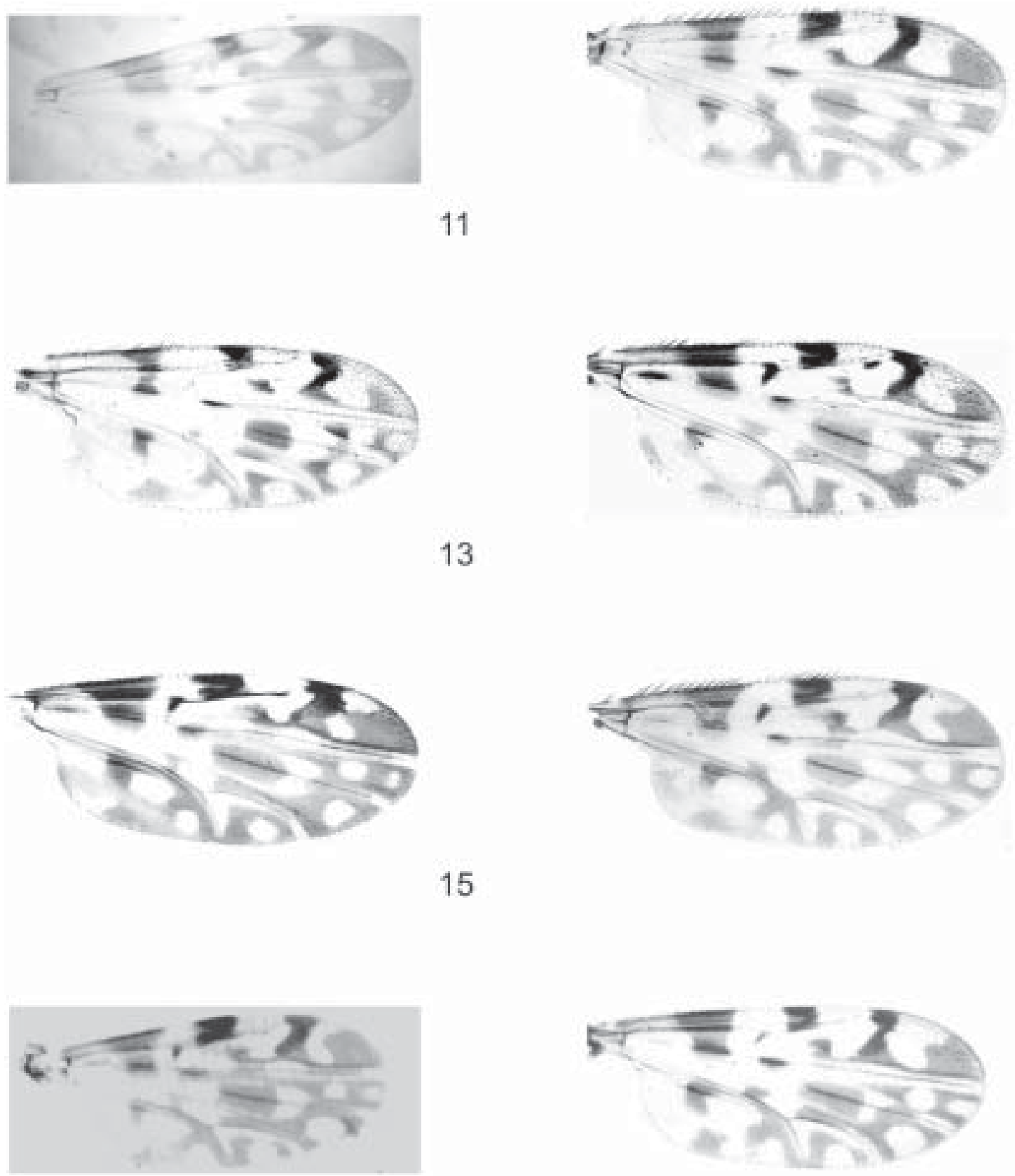

17
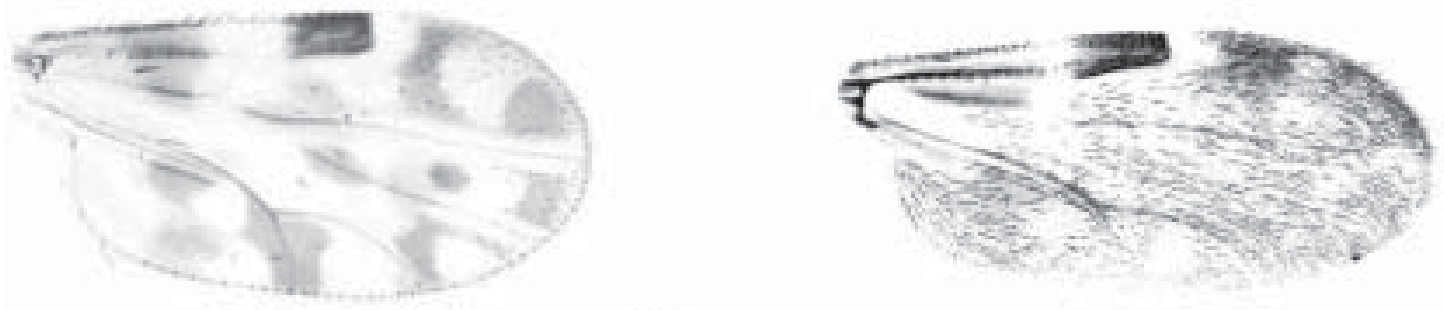

Figs 11-20: photographs of female wings of Culicoides from Argentina. 11: C. ferreyrai; 12: C. lutzi; 13: C. brasilianum; 14: C. foxi; 15: C. fernandoi; 16: C. ignacioi; 17: C. plaumanni; 18: C. guttatus; 19: C. pifanoi; 20: C. uruguayensis. 

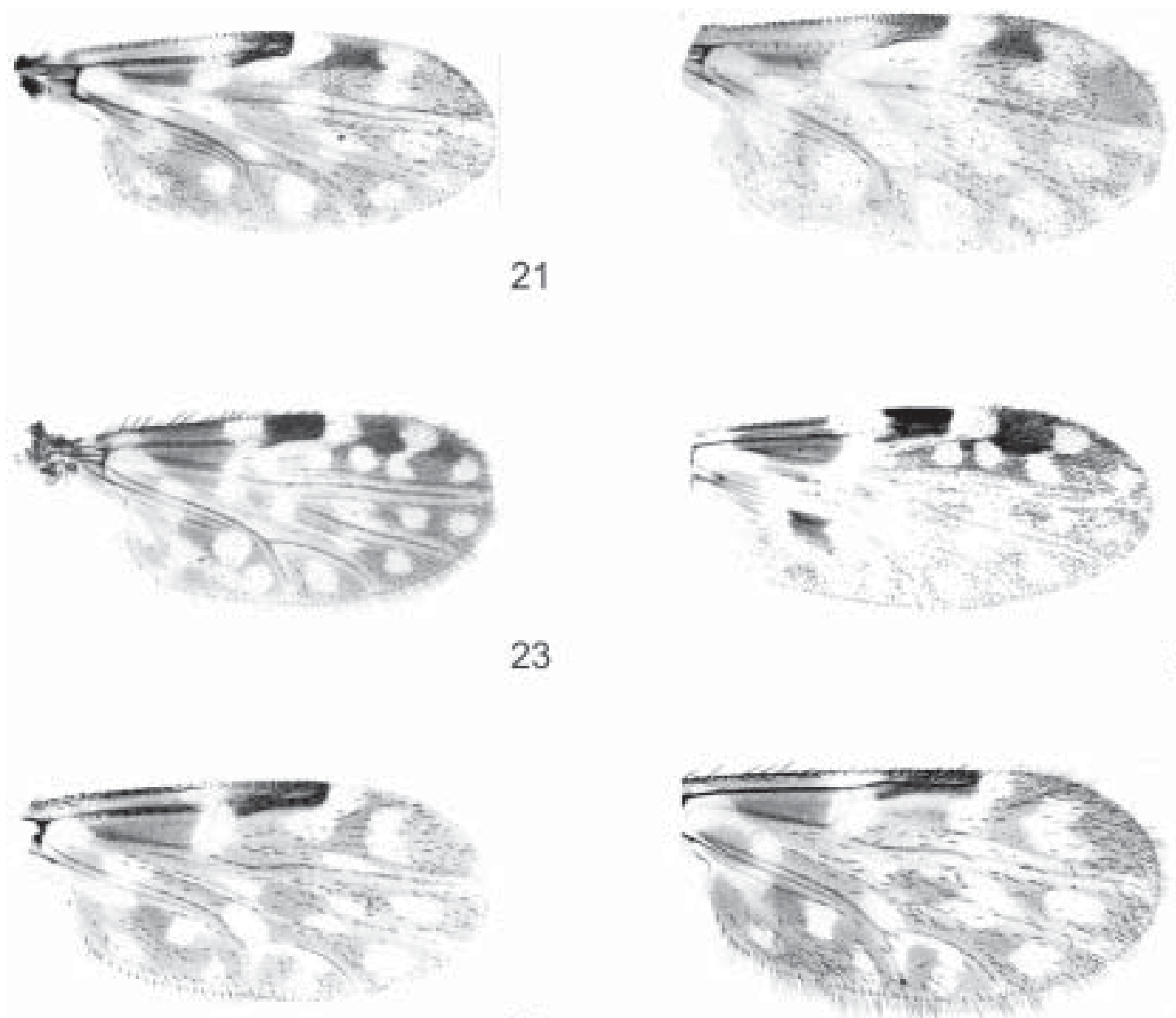

25
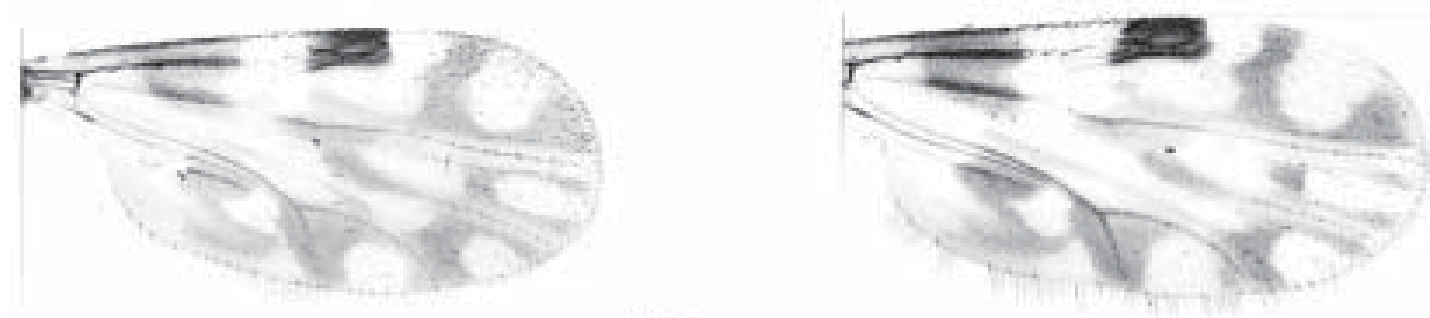

27
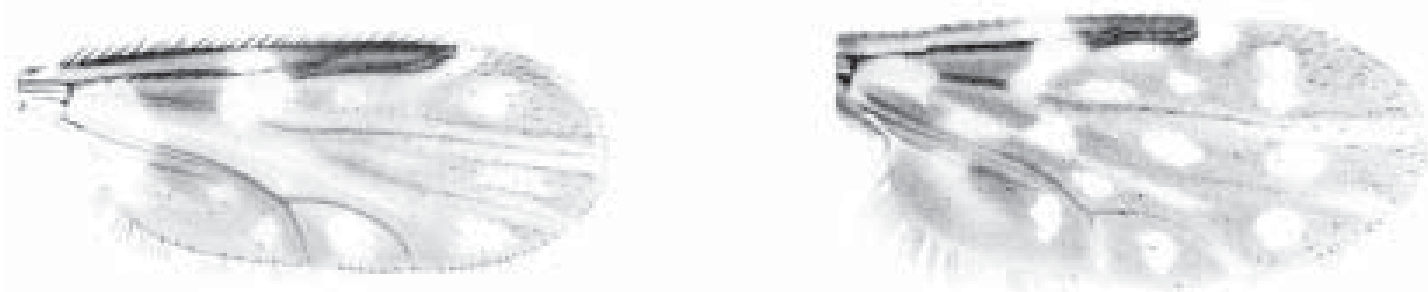

Figs 21-30: photographs of female wings of Culicoides from Argentina. 21: C. chacoensis; 22: C. saltaensis; 23: C. venezuelensis; 24: C. lacustris; 25: C. crescentis; 26: C. pseudocrescentis; 27: C. limai; 28: C. boliviensis; 29: C. cuiabai; 30: C. aureus. 

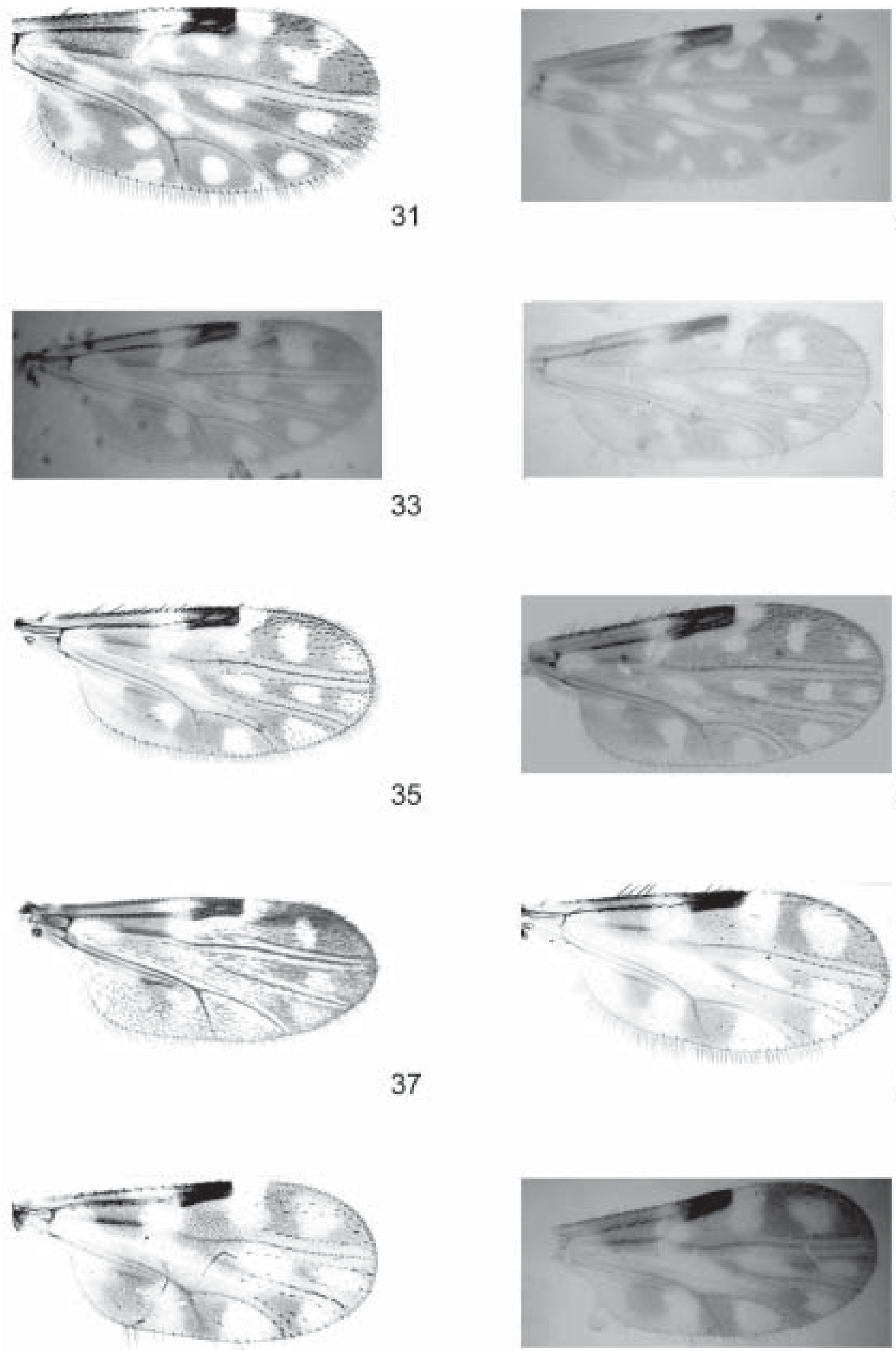

Figs 31-40: photographs of female wings of Culicoides from Argentina. 31: C. leopoldoi; 32: C. williamsi; 33: C. guarani; 34: C. estevezae; 35: C. paraensis; 36: C. austroparaensis; 37: C. trilineatus; 38: C. gabaldoni; 39: C. horticola; 40: C. bachmanni. 
Corrientes province, Santa Tecla, 18 km E Ituzaingó, VII2001, G. Spinelli, CDC light trap. Paratypes, 2 females, same data as types except 8-X-2000.

Derivation of specific epithet - A reference to the southernmost type-locality of species belonging to the $C$. paraensis group.

\section{Culicoides bachmanni Spinelli, n. sp.}

(Figs 40, 53-55)

C. horticola: Ronderos and Spinelli, 1990: 84 (in part, specimens from Buenos Aires province); Ronderos and Spinelli, 1998: 81 (Yacyreta Lake dam area).

Diagnosis - Female: only species of the subgenus Haematomyidium with poststigmatic pale spots in cell $\mathrm{r}_{3}$ fused and longitudinally aligned, and in which flagellomeres 910 are clearly shorter than preceding and following ones. Female. Head: brown. Eyes with scattered pubescence, narrowly separated by distance shorter than diameter of one ommatidium. Flagellum (Fig. 53) pale brown, flagellomeres 9-10 clearly shorter than preceding and following ones; AR $0.58(0.52-0.64, \mathrm{n}=5)$; sensilla coeloconica on flagellomeres 1, 6-8. Palpus (Fig. 54) pale brown; third segment swollen with moderately large, shal- low pit; PR $1.65(1.40-1.95, \mathrm{n}=6)$ ); $\mathrm{P} / \mathrm{H}$ ratio 0.58 (0.56-0.60, $\mathrm{n}=8)$. Mandible with 12-13 $(\mathrm{n}=8)$ teeth.

Thorax: scutum dark brown, without pattern; scutellum, postscutellum dark brown. Legs dark brown, knees darkish; fore, mid femora with subapical, tibiae with subbasal pale rings, hind tibia slightly pale distally; hind tibial comb with four spines, second from spur longest. Wing (Fig. 40), length $0.71(0.64-0.78, \mathrm{n}=9) \mathrm{mm}$; width $0.34(0.30-0.37$, $\mathrm{n}=9) \mathrm{mm}$; CR $0.56(0.53-0.58, \mathrm{n}=9)$; with second radial cell in dark spot; pale spot on crossvein $\mathrm{r}-\mathrm{m}$ small, rounded, barely abutting costal wing margin; poststigmatic pale spots in cell $r_{3}$ fused, longitudinally aligned; distal pale spot in cell $r_{3}$ rounded, located in center of cell, not abutting wing margin; two elongate pale spots in cell $\mathrm{m}_{1}$, distal one narrowly separated from wing margin; cell $\mathrm{m}_{2}$ with small distal pale spot not abutting wing margin, another lying anterior to cubital fork, the latter continuous to conspicuous pale spot extending to crossvein $\mathrm{r}-\mathrm{m}$; cell cua ${ }_{1}$ with rounded pale spot broadly abutting wing margin, reaching distal portion of vein $\mathrm{CuA}_{1}$; anal cell with one distal, large pale spot broadly abutting wing margin; apices of veins $\mathrm{M}_{1}, \mathrm{M}_{2}, \mathrm{CuA}_{1}, \mathrm{CuA}_{2}$ dark. Macrotrichia very sparse on distal fourth of wing. Halter pale.
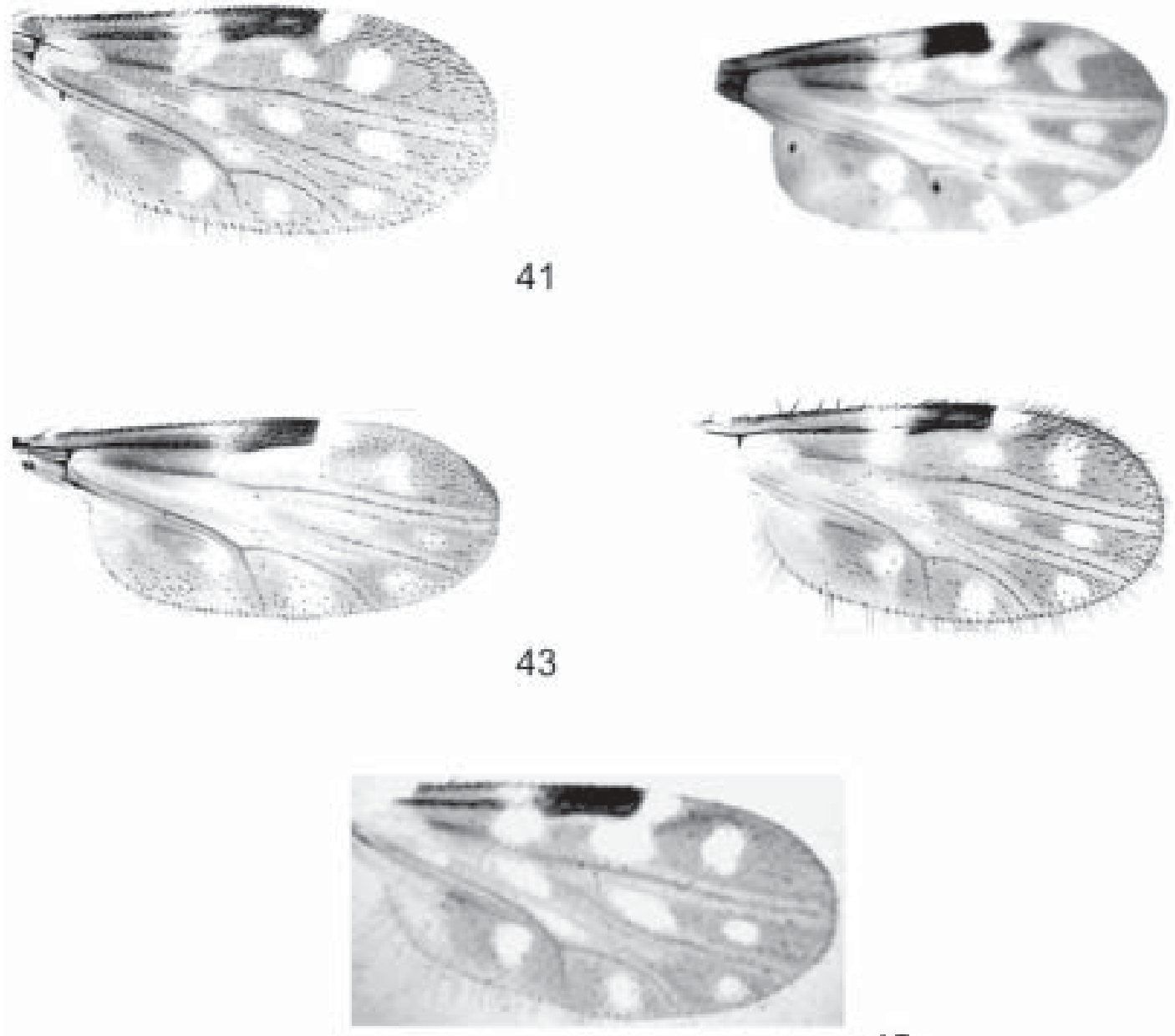

Figs 41-45: photographs of female wings of Culicoides from Argentina. 41: C. ginesi; 42: C. dureti; 43: C. flinti; 44: C. debilipalpis; 45: C. lahillei. 
Abdomen: brown. Two ovoid spermathecae with sclerotized necks (Fig. 55), larger measuring 0.035 (0.028-0.040, $\mathrm{n}=6)$ by $0.029(0.026-0.031, \mathrm{n}=6) \mathrm{mm}$, neck $0.009(0.007$ $0.010, \mathrm{n}=6) \mathrm{mm}$, smaller measuring $0.032(0.026-0.035, \mathrm{n}=$ 6) by $0.027(0.024-0.028, \mathrm{n}=6) \mathrm{mm}$, neck $0.007(0.005-0.008$, $\mathrm{n}=6$ ) $\mathrm{mm}$; rudimentary third, ring present.

Male. Unknown.

Distribution - Argentina (Buenos Aires and Misiones provinces), Paraguay (Itapua).

Taxonomic discussion - This new species belongs to the subgenus Haematomyidium, and keys to couplet 66 in Spinelli and Wirth (1986) where it may be distinguished from C. horticola by the antenna with flagellomeres 9-10 clearly shorter than preceding and following ones.

C. gabaldoni, a species currently placed in the C. leoni species group (Borkent \& Wirth 1997, Borkent \& Spinelli 2000), is also similar to C. bachmanni and C. horticola, especially by its wing pattern with the poststigmatic pale spots in cell $r_{3}$ fused and longitudinally aligned, and by the third palpal segment swollen with moderately large,

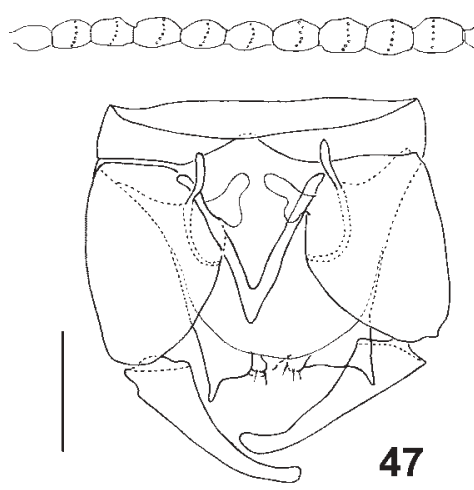

46

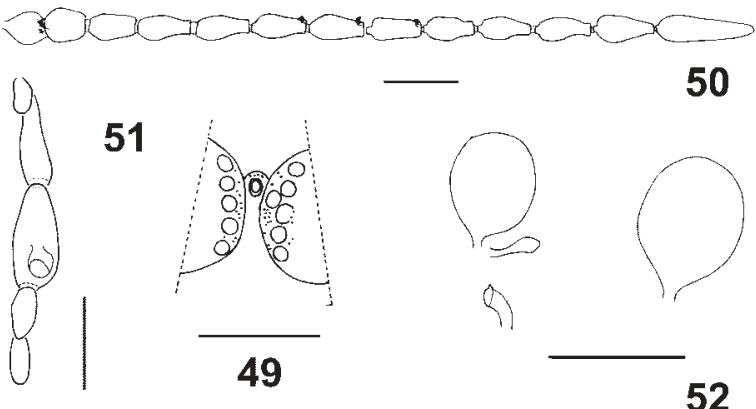

52

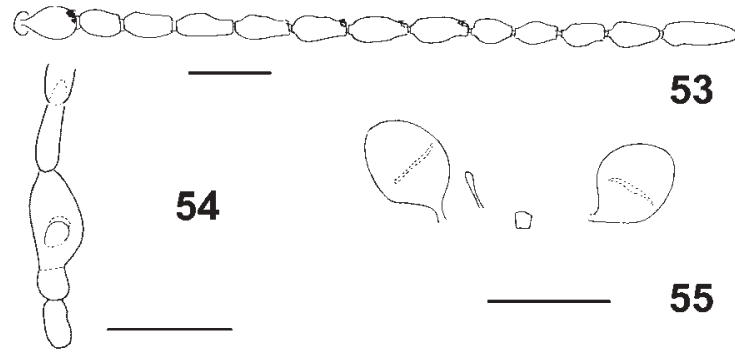

Figs 46-55; 46-52. Culicoides austroparaensis; 53-55: C. bachmanni; 46-48: male; 49-55: female; 46, 50, 53: flagellum; 47: genitalia; 48: parameres; 49: eyes separation; 51, 54: palpus; 52, 55: spermathecae. shallow pit. However, C. gabaldoni differs from both species by the palpus typically pale yellowish and more elongated flagellomeres 11-13.

Types - Holotype female, Argentina, Misiones prov., Corpus, 23-X-2003, A. Giménez, CDC light. Paratypes, 8 females, as follows: same data as holotype, except 10-IV2002, G. Spinelli, 1 female; Misiones prov., Posadas, Mártires stream, 14-VI-1994, G. Spinelli, 1 female, CDC light trap; Misiones prov., 9 de Julio, 11-XI-2003, A. Giménez, 1 female, CDC light trap; Buenos Aires prov., Punta Lara, 25-XI-1985, G. Spinelli - M. Ronderos, 3 females, CDC light trap; Paraguay, Itapua, Encarnación, Santa María stream, 18-X-1993, H. Ferreyra, 1 female, CDC light trap; Paraguay, Mayor Otaño, 11-IV-1994, G. Spinelli, 1 female, CDC light trap.

Derivation of specific epithet - This species is named after Dr Axel O Bachmann (Museo "Bernardino Rivadavia", Buenos Aires, Argentina) in recognition of his important contribution to Entomology in Argentina and his valuable assistance to several young entomologists during the past 50 years.

Culicoides williamsi Spinelli, n. sp. (Figs 32, 56-63)

Diagnosis - Male: only species of the fluvialis species group in which the ventral root of gonocoxite lacks a heellike expansion and with the distal portion of parameres bearing a lateral fringe of fine spicules, which are very inconspicuous. Female is the only species of the fluvialis species group with a narrow pale spot on crossvein r-m, with a separate pale spot distal to crossvein $\mathrm{r}-\mathrm{m}$ in cell $\mathrm{r}_{3}$, and the distal pale spot in cell $\mathrm{r}_{3}$ divided into two smaller, oblique pale spots.

Male. Similar to female with usual sexual differences. Flagellum as in Fig. 56; flagellomeres 2 and 3 strongly fused. Wing length $0.80 \mathrm{~mm}$; width $0.32 \mathrm{~mm}$; CR 0.55 . Genitalia (Fig. 57): tergite 9 tapering gradually, distally without posteromedial notch, apicolateral processes short; sternite 9 short, with shallow posteromedial excavation. Gonocoxite $2.2 \mathrm{X}$ longer than broad, ventral root stout without heellike expansion, dorsal root long, slender; gonostylus broad at base, tapering distally from proximal third, distal portion moderately curved, with broad bent tip. Parameres (Fig. 58) separate, each with large, basal knob; basal portion slender, bent near base, with well developed ventral lobe, distal portion recurved, tapered to slender, sharply pointed tip, with lateral fringe of inconspicuous fine spicules (Fig. 59). Aedeagus with broad, rounded basal arch, extending to 0.60 of total length; basal arms slender, distal portion slender, simple, with narrow rounded apex.

Female. Head brown. Eyes bare, narrowly separated by distance shorter than diameter of one ommatidium. Flagellum (Fig. 60) brown, bases of flagellomeres 2-8 pale; AR $1.16(1.12-1.18, \mathrm{n}=4)$; sensilla coeloconica on flagellomeres 1, 5-8. Palpus (Fig. 61) dark brown; third segment slightly swollen with shallow, subapical pit; PR $1.90(1.80-2.00, \mathrm{n}=4)$; $\mathrm{P} / \mathrm{H}$ ratio $0.63(0.62-0.65, \mathrm{n}=3)$. Mandible with 12-13 $(n=4)$ teeth.

Thorax: scutum dark brown, with conspicuous pattern as illustrated (Fig. 62); scutellum dark brown on broad 
midportion, sides narrowly yellowish, postscutellum dark brown. Legs dark brown; femora with subapical, tibiae with subbasal pale rings, hind tibia pale distally, knees darkish; hind tibial comb with four spines, one nearest spur longest. Wing (Fig. 32), length $0.92(0.86-1.01, \mathrm{n}=4)$ $\mathrm{mm}$; width $0.45(0.42-0.48, \mathrm{n}=4) \mathrm{mm}$; CR $0.61(0.60-0.62$, $\mathrm{n}=4$ ); with second radial cell in dark spot; pale spot on crossvein r-m narrow, broadly abutting costal wing margin; cell $r_{3}$ with small, separate pale spot distal to crossvein $\mathrm{r}-\mathrm{m}$, poststigmatic pale spots subequal, posterior one located proximal to first; distal pale spot in cell $r_{3}$ divided in two smaller, oblique pale spots, distal most barely abutting wing margin; two pale spots in cell $\mathrm{m}_{1}$, distal most well separated from wing margin; cell $\mathrm{m}_{2}$ with two elongate pale spots on distal portion, distal most small, not abutting wing margin, another pale spot lying anterior to cubital fork, another behind crossvein $\mathrm{r}-\mathrm{m}$; cell cua ${ }_{1}$ with small pale spot not abutting wing margin nor veins $\mathrm{CuA}_{1}$, $\mathrm{CuA}_{2}$; anal cell with two distal pale spots, distal one barely abutting wing margin, irregular pale area at base; apices of veins $\mathrm{M}_{1}, \mathrm{M}_{2}, \mathrm{CuA}_{1}$ with small pale spots, apex of vein $\mathrm{CuA}_{2}$ dark. Macrotrichia few, scattered on distal fourth of wing membrane. Halter dark brown.

Abdomen: brown. Two ovoid spermathecae with long, sclerotized, recurved necks (Fig. 63), larger measuring 0.059 $(0.058-0.060, \mathrm{n}=4)$ by $0.050(0.048-0.053, \mathrm{n}=4) \mathrm{mm}$, neck $0.021(0.020-0.022, \mathrm{n}=4) \mathrm{mm}$, smaller measuring 0.049
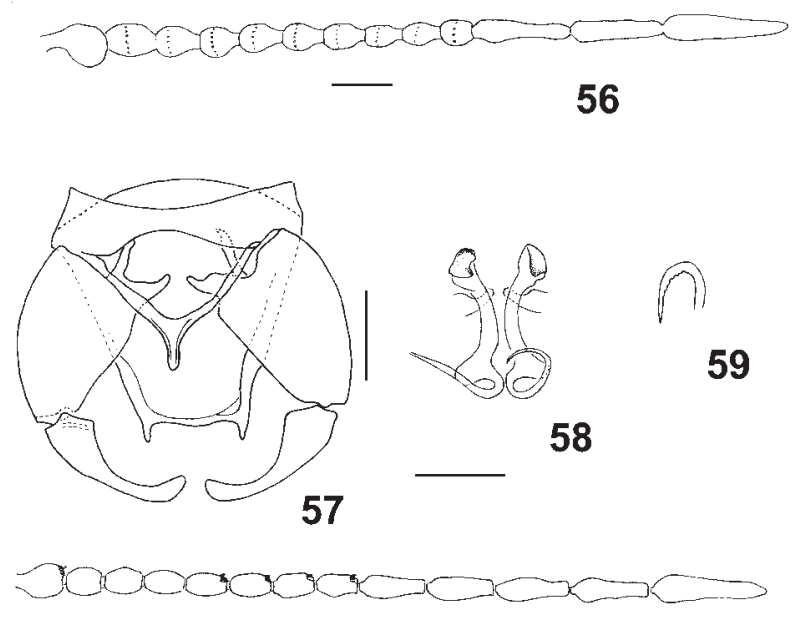

60

61
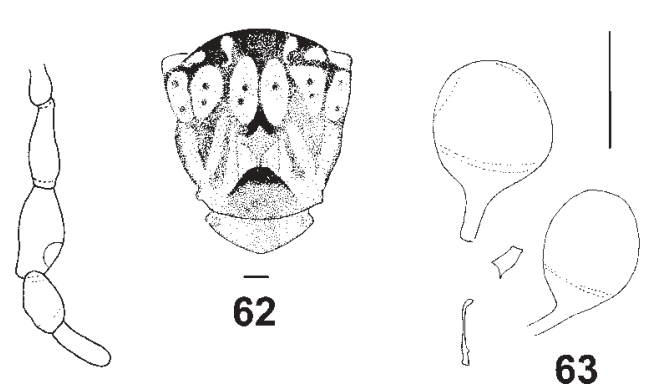

Figs 56-63: Culicoides williamsi; 56-59: male; 60-63: female. 56, 60: flagellum; 57: genitalia; 58: parameres; 59: detail tip of parameres; 61: palpus; 62: scutum; 63: spermathecae.
$(0.046-0.050, \mathrm{n}=4)$ by $0.040(0.038-0.043, \mathrm{n}=4) \mathrm{mm}$, neck $0.019(0.017-0.020, \mathrm{n}=4) \mathrm{mm}$; rudimentary third, ring present.

Distribution - Argentina (Formosa province); Paraguay (Itapua).

Taxonomic discussion - This new species belongs to the C. fluvialis species group, and keys to couplet 48 in Spinelli and Wirth (1986) where it may be distinguished from $C$. leopoldoi by the presence of two spermathecae (one in C. leopoldoi). The wing pattern of $C$. leopoldoi is also very similar to that $C$. williamsi, but it can be distinguished by the extensive pale spot on crossvein $\mathrm{r}-\mathrm{m}$, the presence of a pale spot behind second radial cell proximal to the poststigmatic pale spots, these pale areas longitudinally aligned, the posterior one smaller, and by the distal pale spot in cell $r_{3}$ large with narrow proximal extension.

The male and female of this species were associated by their shared pigmentation patterns and were collected together at the type locality.

Types. Holotype male, allotype female, Paraguay, Itapua, Ayolas, refugio Atinguy, 25-III-2004, D. López - A. Ortiz, CDC light trap. Paratypes, 3 females, as follows: same data as types, 2 females; Argentina, Formosa province, Estancia La Marcela, $35 \mathrm{~km}$ E El Colorado, 27/28-VII-2003, J. Williams, at light.

Derivation of specific epithet - This species is named after Prof. Jorge D. Williams, herpetologist at the Museo de La Plata, Argentina, in recognition of his friendship and important help collecting ceratopogonids.

New records

\section{Leptoconops (Leptoconops) brasiliensis (Lutz)}

Tersesthes brasiliensis Lutz, 1913: 66 (female; Brazil); Gezuelo and Franca-Rodríguez, 1972: 39 (Uruguay record).

L. brasiliensis: Lane, 1945: 358 (comb.; type redescr.).

L. (Leptoconops) brasiliensis: Ronderos and Spinelli, 1992: 43 (in key to Neotropical species); Borkent and Spinelli, 2000: 9 (in Neotropical catalog; distrib.).

Specimens examined - Argentina, Salta prov., Molinos, 19-I-2000, G. Spinelli, 1 female, biting man.

Distribution - Northwestern Argentina; Brazil (Amazonas); Uruguay.

\section{Culicoides estevezae Ronderos and Spinelli}

C. estevezae Ronderos and Spinelli, 1994: 47 (female; Argentina, Salta province); Borkent and Spinelli, 2000: 38 (in Neotropical catalog; distrib.).

Specimens examined - Argentina, Misiones prov., Campo Viera, 7/9-X-1982, G. Spinelli, 1 female, Shannon light trap.; Misiones prov., Corpus, 23-X-2003, A. Giménez, 1 female, CDC light trap.

Distribution - Northwestern and northeastern Argentina.

\section{Culicoides gabaldoni Ortiz}

C. gabaldoni Ortiz, 1954: 221 (female; Venezuela); Wirth and Blanton, 1959: 431 (redescr.; Panama); Vitale et al. 1981: 146 (in key, C. debilipalpis group); Wirth et al. 1988: 48 (wing photo); Ronderos and Spinelli 1998: 81 (Paraguay record); Borkent and Spinelli 2000: 39 (in Neotropical catalog; distrib.). 
Specimens examined - Argentina, Misiones prov., Corpus, 7-VI-2000, G. Spinelli, 1 female, CDC light trap; same data except, 10-IV-2002, A. Giménez, 2 females.

Distribution - Mexico (Tabasco) to Ecuador, Venezuela, Trinidad, Brazil (Bahia), Paraguay, northeastern Argentina.

\section{Culicoides ginesi Ortiz}

C. ginesi Ortiz, 1951: 586 (female; Venezuela); Wirth and Blanton 1959: 450 (redescr.; Panama); Wirth and Blanton 1973: 436 (Brazil record); Vitale et al. 1981: 146 (in key, $C$. debilipalpis group); Wirth et al. 1988: 48 (wing photo); Borkent and Spinelli 2000: 32 (in Neotropical catalog; distrib.).

Specimens examined - Argentina, Misiones prov., Anyico stream and national route $\mathrm{nr} 14(\mathrm{~km} 813$, aproximately 30 kn N San José), 4-XI-2002, G Spinelli, 4 females, at light. Distribution - El Salvador to Panama, Colombia, Venezuela, Trinidad, Brazil (Para), northeastern Argentina.

\section{Culicoides pifanoi Ortiz}

C. pifanoi Ortiz, 1951: 588 (male, female; Venezuela); Wirth and Blanton 1959: 384 (redescr.; Panama; syn.); Wirth and Blanton 1973: 444 (Pará record); Spinelli and Wirth 1986: 63 (Bahia record); Wirth et al. 1988: 40 (wing photo); Borkent and Spinelli 2000: 41 (in Neotropical catalog; distrib.).

C. tricoloratus Wirth and Blanton 1953: 233 (female, male; Panamá).

Specimens examined - Paraguay, Itapua, Refugio Atinguy, V-2004, A Ortiz - D López, 2 females, CDC light trap.

Distribution - Belize to Colombia, Venezuela, Trinidad, Brazil (Pará, Bahia), Paraguay (Itapua).

\section{Culicoides pseudocrescentis Tavares and Luna Dias}

C. pseudocrescentis Tavares and Luna Dias 1980: 397 (male; Brazil); Wirth et al. 1988: 30 (wing photo); Borkent and Spinelli 2000: 38 (in Neotropical catalog; distrib.).

Specimens examined - Argentina, Misiones prov., Anyico stream and national route $\mathrm{nr} 14(\mathrm{~km} \mathrm{813}$, aproximately 30 kn N San José), 4-XI-2002, G Spinelli, 1 female, at light; Paraguay, Itapua, Bella Vista, IV-1998, A Ortiz - D López, 1 female, CDC light trap.

Distribution - Brazil (Rio de Janeiro), Paraguay (Itapua), Argentina (Misiones).

\section{Culicoides trilineatus Fox}

C. trilineatus Fox, 1946: 250 (female; Virgin Islands); Wirth and Blanton 1956: 189 (redescr.); Vitale et al. 1981: 146, 148 (in key, C. debilipalpis group); Wirth et al. 1988: 50 (wing photo); Borkent and Spinelli 2000: 42 (in Neotropical catalog; distrib.).

Specimens examined - Paraguay, Itapua, Aguapey, 1/2XI-2000, A Ortiz - D López, 1 female, CDC light trap.

Distribution - Guatemala to Panama, Puerto Rico, Virgin Islands, Dominica, Barbados, Paraguay.

\section{ACKNOWLEDGMENTS}

To Drs Art Borkent, William Grogan for their detailed critical review of the manuscript acting as a journal referees.

\section{REFERENCES}

Borkent A, Spinelli GR 2000. Catalog of the New World biting midges south of the United States of American (Diptera: Ceratopogonidae). Contrib Entomol Intern 4: 1-107.

Borkent A, Wirth WW 1997. World species of biting midges (Diptera: Ceratopogonidae). Bull Am Mus Nat History 233: 257.

Felippe-Bauer ML, Caceres AG, Silva CS, Valderrama-Bazan W, Gonzales-Perez A 2003. Two new Culicoides of the paraensis species group (Diptera: Ceratopogonidae) from the Amazonian region of Peru. Mem Inst Oswaldo Cruz 98: 1051-1058.

Forattini OP 1957. Culicoides da Região Neotropical (Diptera: Ceratopogonidae). Arq Fac Hig Saúde Pub Univ São Paulo 11: 159-526.

Fox I 1946. A review of the species of biting midges or Culicoides from the Caribbean Region (Diptera: Ceratopogonidae). Ann Entomol Soc Am 39: 248-258.

Gezuelo E, Franca-Rodríguez ME 1972. Tersesthes brasiliensis capturado en Uruguay (Diptera: Ceratopogonidae). Rev Inst Nac Hig 5: 37-45.

Lane J 1945. Redescrição de Ceratopogonídeos Neotrópicos (Diptera: Ceratopogonidae). Rev Ent 16: 357-372.

Lutz A 1913. Contribução para o estudo das Ceratopogoninas hematofagas do Brazil. Mem Inst Oswaldo Cruz 5: 45-73.

Marino PI, Spinelli GR 2005. First descriptions of females of two Neotropical species of Forcipomyia. Deut Entomol $Z$, in press.

McAlpine JF, Peterson BV, Shewell GE, Teskey HJ, Vockeroth JR, Wood DM 1981. Manual of Nearctic Diptera, Vol. 1, Agriculture Canada Monograph 27, 674 pp.

Ortiz I 1951. Estudios en Culicoides (Diptera, Ceratopogonidae) IX. Sobre los caracteres diferenciales entre Culicoides paraensis (Goeldi, 1905), C. stellifer (Coquillett, 1901) y C. lanei (Ortiz, 1950). Descripción de cuatro nuevas especies con la redescripción de algunas otras poco conocidas. Rev Sanid Asist Social 16: 573-591.

Ortiz I 1954. Sobre dos nuevos dipteros hematófagos del género Culicoides (Nematocera: Ceratopogonidae). Arch Venezolanos Patol Trop y Parasit Méd 2: 221-226.

Ronderos MM, Spinelli GR 1990. Further notes on Culicoides Latreille 1809 from Argentina (Insecta, Diptera, Ceratopogonidae). Iheringia Sér Zool 70: 81-88.

Ronderos MM, Spinelli GR 1992. A key to the Neotropical Leptoconops (Diptera: Ceratopogonidae), with the description of the new species from Argentina. Rev Soc Entomol Argent 51: 41-45.

Ronderos MM, Spinelli GR 1994. Dos especies nuevas de Culicoides de la Argentina (Diptera: Ceratopogonidae). Rev Soc Entomol Argent 53: 47-50.

Ronderos MM, Spinelli GR 1998. Las especies de Culicoides en el área de influencia de la represa de Yacyretá (Diptera: Ceratopogonidae). Rev Soc Entomol Argent 57: 79-83.

Ronderos MM, Spinelli GR 1999. On the subgenus Forcipomyia (Lasiohelea) in the Neotropical Region (Diptera: Ceratopogonidae). Trans Amer Entomol Soc 125: 151-161.

Ronderos MM, Spinelli GR 2002. Los Culicoides de la Argen- 
tina: clave de especies y nuevos registros (Diptera: Ceratopogonidae). In D Salomón, Actualizaciones en Artropodología Sanitaria Argentina, Fundación Mundo Sano, Buenos Aires. 302 pp.

Ronderos MM, Spinelli GR, Lager I, Díaz F 2003. La importancia de los jejenes del género Culicoides (Diptera: Ceratopogonidae) en la Argentina. Entomol Vect 10: 601612.

Spinelli GR, With WW 1986. Clave para la identificación de las especies del género Culicoides Latreille presentes al sur de la cuenca Amazónica, nuevas citas y notas sinonímicas (Diptera: Ceratopogonidae). Rev Soc Entomol Argent 44: 49-73.

Szadziewski R 1996. Biting midges from Lower Cretaceous amber of Lebanon and Upper Cretaceous Siberian amber of Taimyr (Diptera, Ceratopogonidae). Studia Dipterol 3: 23-86.

Tavares OP, Luna Dias AP 1980. Quatro novas espécies do genero Culicoides Latreille, 1809, do Estado do Rio de Janeiro, Brasil (Diptera: Ceratopogonidae). Rev Bras Biol 40: 393-399.

Vitale GC, Wirth WW, Aitken THG 1981. New species and records of Culicoides reared from arboreal habitats in Panama, with a synopsis of the debilipalpis group (Diptera: Ceratopogonidae). Proc Ent Soc Wash 83: 140-159.

Wirth WW, Blanton FS 1953. Studies in Panama Culicoides (Diptera, Heleidae). II. Descriptions of six additional new species. J Parasitol 39: 229-236

Wirth WW, Blanton FS 1956. Redescriptions of four species Neotropical Culicoides of the debilipalpis group (Diptera: Heleidae). J Wash Acad Sci 46: 186-190.

Wirth WW, Blanton FS 1959. Biting midges of the genus Culicoides from Panama (Diptera: Heleidae). Proc US Nat Mus 109: 237-482.

Wirth WW, Blanton FS 1973. A review of the maruins or biting midges of the genus Culicoides (Diptera: Ceratopogonidae) in the Amazon Basin. Amazoniana 4: 405-470.

Wirth WW, Dyce AL, Spinelli GR 1988. An atlas of wings photographs, with a summary of the numerical characters of the Neotropical species of Culicoides (Diptera: Ceratopogonidae). Contrib Amer Entomol Inst 25: 1-72.

Wirth WW, Felippe-Bauer ML 1989. The Neotropical biting midges related to Culicoides paraensis (Diptera: Ceratopogonidae). Mem Inst Oswaldo Cruz 84: 551-565. 